\title{
FINANCIAL INSTRUMENTS OF THE STATE POLICY FOR THE PREVENTION OF TERRORIST ACTS IN UKRAINE
}

\author{
Mykola BUNCHUK ${ }^{1}$ \\ National Academy for Public Administration under the President of Ukraine, Ukraine
}

\begin{abstract}
The article's objective is to determine the mechanism for implementing the financial instruments of the state policy to counter terrorist acts in the territory not controlled by Ukrainian authorities in Donetsk and Luhansk regions. Methodology. Within the scientific research, for the most effective approaches at the national level to prevent the threat of international terrorism, under the conditions of the deep internal political crisis and extremely difficult economic situation, in order to improve the efficiency of public administration in developing and implementing the anti-terrorism state policies in Ukraine, the paper analyses international and domestic regulations on preventing the terrorist financing, considers factors that affect the deterioration of the social and economic situation of the temporarily occupied parts of Donbas. Results of the research allow formulating the definition of financial instruments of antiterrorist policies, the paper develops and proposes a series of organizational measures in order to prevent the terrorist financing in Ukraine. Practical implications. Based on the above, we propose an option of classification of main illegal mechanisms that may be used to finance terrorist activities in the territories of Donetsk and Luhansk regions uncontrolled by Ukrainian authorities, dividing them into internal and external. Given the above studied factors and classification of financing of terrorist acts in eastern Ukraine, we can assume that for the purpose of evading duty payable to relevant state bodies of Ukraine, external supplies of inventories in the uncontrolled areas of the Donetsk region, which are later obtained by illegal armed groups, are possibly carried out as follows: on behalf of a commercial entity registered in a foreign country for the Ukrainian commercial entity, registered in settlements located in the uncontrolled territory; crossing of international transit traffic that moves through the Russian Federation checkpoints of the Ukrainian-Russian border on the uncontrolled Ukrainian territory. Value/originality. We have concluded that the introduction of financial instruments of the state policy to counter terrorism will bring the following positive results: ensure systematic implementation of the state policy in the prevention and counteraction to legalization (laundering) of proceeds from crime or terrorist financing; enhance a compliance of the national system of combating legalization (laundering) of proceeds from crime or terrorism financing with the international legal standards; improve inflow of foreign investment in order to stimulate the national economy. However, the effectiveness of the above measures should be determined in accordance with the principles of economic analysis of the state policy.
\end{abstract}

Key words: money laundering, state anti-terrorism policy, policy instruments, financial and economic mechanism, terrorism financing.

JEL Classification: R13, K14, P16, H72, J18

\section{Introduction}

The search for the most effective approaches at the national level to prevent the threat of international terrorism, the identification of promising vectors of international cooperation in this area gain a particular importance for Ukraine, which is forced to rethink its external positioning and the previously declared nature of the strategic partnership in the conditions of deep internal crisis and extremely difficult foreign policy situation due to the events in the East of Ukraine and in Crimea.
In this sense, the emergence of programs to finance the fight against terrorism in a number of countries, including the improvement of measures to combat terrorist financing, attracts attention. In the future, the process of implementing reforms in the country, particularly in terms of the EU-Ukraine Association Agreement (Law of Ukraine N 1678-VII, 2014), provides for anti-terrorism cooperation based on the performance of UN Security Council Resolution N 1373 of 2001, the UN Global CounterterroristStrategy 2006 and other UN documents (Portal UN SC) and

Corresponding author:

${ }^{1}$ Department of Management of National Economy and Economic Policy, National Academy for Public Administration

under the President of Ukraine.

E-mail: nick-nick.71@mail.ru 
the relevant international conventions and regulations, thus envisaging the deepening of cooperation in order to combat money laundering and financing of terrorism within the operation of the Financial Action Task Force (FATF).

According to the above, Ukraine should join the international practice of preventing the terrorist financing that will significantly reduce the risk of terrorist attacks with minimal costs.

Thus, at the date, scientists, politicians, and economists are facing an urgent need to develop and implement effective financial and economic measures to overcome the terrorist acts through the regulation of the hybrid military conflict in Donbas by the antiterrorist legislation.

The purpose of the article is to determine the mechanism for implementing the financial instruments of the state policy to counter terrorist acts in the territory not controlled by Ukrainian authorities in Donetsk and Luhansk regions.

\section{Recent research and publications analysis}

A significant contribution has been made by such prominent domestic and foreign authors as A. Abadi, J. Gardeazabal, A. Vining, D. Weimer, M. Viscusi, Kh. Liang, O. Kiliievych, A. Mertens, I. Rozputenko, J. Stiglitz and others. The key attention of the authors has been paid to the analysis of social and economic factors of terrorism, financing sources, and analysis of the state policy, in particular, an efficiency of measures to protect from transnational terrorism at the national and international levels.

They have also introduced the concept of catastrophic risk from terrorism in the standard model of endogenous growth and analysed the effect of increased terrorist risk in accordance with the positions of countries on foreign direct investments. Thus, in the integrated global economy where international investors are able to diversify other risks, terrorism can cause a large movement of capital between countries (Abadie, Gardeazabal, 2006).

At the same time, scientists believe that the creation of modern forms of terrorism is brightly demonstrated by the creation of the Islamic State, the richest terrorist organization in the history with the estimated wealth of 2 billion US dollars. This has been caused by the ability of the Islamic State to take control over the autonomous territory and reign it by using the marketing tools of the 21 st century to create an international brand in the strategy of attracting foreign soldiers (Schori Liang, 2015). Therefore, some international financial and economic tools, particularly to counter the Islamic State, in our opinion, may be useful when overcoming the financial problems associated with terrorist manifestations in Ukrainian Donbas.

\section{The paper main body}

The Law of Ukraine "On Prevention and Counteraction to Legalization (Laundering) of Proceeds from Crime or Terrorist Financing" states that the state financial monitoring is a set of actions taken by state financial monitoring units designed to meet the requirements of the law on the prevention and counteraction to legalization (laundering) of proceeds from crime terrorist financing (Law of Ukraine N 1702VII, 2014).

The regulatory law also states that the main objectives of state financial monitoring units as a specially authorized body are to implement the state policy in combating legalization (laundering) of proceeds from crime or terrorist financing.

Thus, on the demand of the implementation of Article 18 of the abovementioned Law of Ukraine, by Decree No. 1407-r dated December 30, 2015, the Cabinet of Ministers of Ukraine approved the strategy of development of the system of prevention and counteraction to legalization (laundering) of proceeds from crime, terrorist financing and financing of proliferation of weapons of mass destruction by 2020 (Decree of the Cabinet Ministers Ukraine № 1407-p, 2015).

The aim of the Strategy is a legal, organizational and institutional improvement and provision of stable operation of the national system of prevention and counteraction to legalization (laundering) of proceeds from crime, terrorist financing and financing of proliferation of weapons of mass destruction.

It is expected that the implementation of this Strategy will help ensure:

- systematic implementation of the state policy in combating legalization (laundering) of proceeds from crime, terrorist financing and financing of proliferation of weapons of mass destruction in accordance with the international standards;

- harmonization of the national system of combating legalization (laundering) of proceeds from crime, terrorist financing and financing of proliferation of weapons of mass destruction with the international standards;

- reduction of the corruption level;

- effective cooperation and continuous exchange of information with executive authorities, other public bodies - state financial monitoring units, and competent authorities of foreign states and international organizations in this area;

- training of government officials in financial monitoring and employees of primary financial monitoring units;

- transparent and efficient use of the state budget;

- stimulation of the inflow of foreign investments into the national economy;

- filling of the revenue part of the state budget; 
- promotion of the liberalization of the EU visa regime for Ukraine.

So, based on the legislative acts of Ukraine with the purpose of forming a monitoring system in the ATO area, combating smuggling, as well as identifying persons involved in terrorist activities, the "temporary mode of control over the movement of persons, vehicles and goods across the conflict line within the Donetsk and Luhansk regions" has been replaced by the Resolution of the Cabinet of Ministers of Ukraine dated March 1, 2017 No. 99 approving the "procedure for the movement of goods to and from the antiterrorist operation area". This procedure has been adopted pursuant to the Decision of the National Security and Defence Council of Ukraine dated February 16, 2017 "On Urgent Measures to Neutralize Threats to the Energy Security of Ukraine and Enhance the Protection of Critical Infrastructure" approved by the Decree of the President of Ukraine No. 37/2017.

Based on the above, in order to further define the characteristics of financial and economic instruments of the state counter-terrorism policy that have emerged in terms of the anti-terrorist operation in eastern Ukraine, we have determined the factors that affect the deterioration of the social and economic status of Donbas:

- destruction and transfer of production facilities of the Donetsk and Luhansk regions to the territory of the Russian Federation;

- outflow of the intellectual potential of the regions;

- lack of synchronization between the financial and banking systems of the main part of Ukraine and of the regions beyond the control (inability to provide social benefits, including pensions);

- problems of the fuel and energy sector due to the lack of gas/electricity in some areas related to the destruction of gas transmission systems and suspension of energy supply due to the lack of payments for consumption;

- decline of the coal industry through the closure of most mines and transition to illegal coal mining;

- lack of jobs for the population;

- growth of the protest potential of the population due to increased salary arrears;

- shortage of food and basic necessities and sale at an unreasonably high price;

- ban of the sale of goods, other that manufactured in

Russia, in the territories outside the control of Ukraine; - non-state control, so-called "protection racket", of certain sectors of economic activities and money laundering of the "administrative elite" of the temporarily occupied territories of Donbas.

Based on the above, we propose an option of the classification of main illegal mechanisms that may be used to finance terrorist activities in the territories of Donetsk and Luhansk regions uncontrolled by Ukrainian authorities, dividing them into internal and external.
Internal:

- hidden import of cash to conduct financial transactions using payment cards (pensions and social benefits); - import of inventories in the violation of regulatory requirements of the procedure for movement of goods; - concealing of profits of enterprises that have been re-registered in Ukraine, and which in fact are located in the uncontrolled territories of Donbas;

- leaving exports to the uncontrolled areas;

- a part of goods for humanitarian convoys from the main territory of Ukraine is sold for cash in the uncontrolled parts of Donbas;

- illegal payment of customs duties to "fiscal structures" of the uncontrolled areas of Donbas.

External:

- receipt of funds from the sale of marketable products and equipment of industrial enterprises outside the uncontrolled Donbas;

- no opportunity for state accounting of cash and imported goods, including military goods of the Russian Federation under the guise of humanitarian convoys;

- external funding of various programs uncontrolled by Ukraine (economic, social, military, security, etc.) for the development of the temporarily occupied territories and commercial investment projects in order to implement measures aimed at discrediting the government of Ukraine before the local population; - establishment of foreign economic relations by certain foreign commercial entities with companies controlled by terrorist organizations.

Given the above studied factors and classification of financing of terrorist acts in eastern Ukraine, we can assume that for the purpose of evading duty payable to relevant state bodies of Ukraine, external supplies of inventories in the uncontrolled areas of the Donetsk region, which are later obtained by illegal armed groups, are possibly carried out as follows:

- on behalf of a commercial entity registered in a foreign country for the Ukrainian commercial entity, registered in settlements located in the uncontrolled territory;

- crossing of international transit traffic that moves through the Russian Federation checkpoints of the Ukrainian-Russian border on the uncontrolled Ukrainian territory.

Thus, the anti-terrorist policy tools to prevent the funding of the so-called People's Republic of Donetsk and Luhansk People's Republic are considered by us to be as follows:

- methodological and practical support in prevention and counteraction to legalization (laundering) of proceeds from crime or terrorist financing;

- use by primary financial monitoring units of measures to strengthen the requirements for reclamation/ clarification of the information required for the implementation of the "know your customer" rules, including on the basis of information from public sources, namely, the Internet, social networks, etc.; 
- strengthening of control over payment systems and non-bank financial institutions in terms of expansion of the internal financial monitoring requirements; - review of the state regulations governing payments in cash, for the purpose of reduction of marginal amounts of cash transactions;

- strengthening of control over the activities of nonprofit organizations;

- strengthening of interagency cooperation between state regulators, primary financial monitoring units, the State Financial Monitoring Service and law enforcement agencies;

- strengthening of international cooperation in countering terrorist and separatist activities.

Thus, given the fact that credit and financial institutions are the most "attractive" for the legalization (laundering) of money in Ukraine and worldwide, in order to prevent terrorist financing in Ukraine, it is expedient to take a number of organizational measures and, above all,

- to minimize cash flows through increased use of electronic payments;

- to introduce modern forms of accountability that would ensure strict control of money circulation;

- to provide employees of search and detective units with more powers to obtain information on financial and economic activities of individual investors;
- to unify the national legal framework; a common system to monitor the movement of cash and cashless transactions to prevent terrorist groups from concealing their capital.

\section{Conclusions}

Considering the study of provisions of the national and international regulations, we have concluded that the introduction of financial instruments of the state policy to counter terrorism will bring the following positive results: - ensure systematic implementation of the state policy in the prevention and counteraction to legalization (laundering) of proceeds from crime or terrorist financing; - enhance compliance of the national system of combating legalization (laundering) of proceeds from crime or terrorism financing with the international legal standards;

- improve the inflow of foreign investment for the stimulation of the national economy.

With due regard to international standards, the urgent need to establish effective organizational and regulatory measures of prevention and counteraction to legalization (laundering) of proceeds from crime is evident (Kiliievych, 2011). However, the effectiveness of the above measures should be determined in accordance with the principles of economic analysis of the state policy.

\section{References:}

Law of Ukraine "On the ratification of the Association Agreement between Ukraine and the European Union" dated September 16, 2014 N 1678-VII [Electronic resource]. - Retrieved from: http://www.kmu.gov.ua/control/ publish/article?art_id=246581344.

Portal of the UN Security Council. [Electronic resource]. - Retrieved from: http://www.un.org/ru/sc/

Alberto Abadie, Javier Gardeazabal (2006). Terrorism and the World Economy. European Economic Review. January, 107-192.

Christina Schori Liang/ISIL inc.: (2015). A portrait of a modern terrorist enterprise. Global Terrorism Index, 76-80.

Law Ukraine «On the Prevention and Counteraction to Legalization (Laundering) of Proceeds from Crime orTerrorist Financing" dated November 28, 2002. Supreme Council of Ukraine. 2003. No. 1.

Decree of the Cabinet Ministers Ukraine dated December 30, 2015 "On the strategy of development of the system of prevention and counteraction to legalization (laundering) of proceeds from crime, terrorist financing and financing of proliferation of weapons of mass destruction by 2020" // [Electronic resource]. - Access mode: http://www.kmu.gov.ua/control/uk/publish/article?art_id=248755388

Temporary mode of control over the movement of persons, vehicles and goods across the conflict line within the Donetsk and Lugansk regions (Decree of the First Deputy Head of the ATC at the Security Service of Ukraine the Head of the Antiterrorist Operation in the Donetsk and Lugansk Regions dated November 22, 2015 No. 27og., latest version - Decree No. 415og dated June 12, 2015, latest modifications dated December 16, 2015). [Electronic resource]. - Retrieved from: Zakon.golovbukh.ua/regulations/2341/8374/8375/465003/.

Resolution of the Cabinet of Ministers of Ukraine from March 1, $2017 \mathrm{r}$. Number 99 On approval of the transfer of goods to the area or the area of the antiterrorist operation. [Electronic resource]. - Retrieved from: http://www.kmu.gov.ua/control/ru/cardnpd?docid=249790429

Decree of the President of Ukraine No. 37/2017 On the Decision of the National Security and Defense Council of Ukraine dated February 16, 2017 "On Urgent Measures to Neutralize Threats to the Energy Security of Ukraine and Enhance the Protection of Critical Infrastructure". [Electronic resource]. - Retrieved from: http://www.president.gov.ua/documents/372017-21302

Kiliievych O.I. (2011). Economic analysis of the State Policy, textbook. - K.: NADU, 80 p. 
Vol. 3, No. 1, 2017

\section{Николай БУнчук}

\section{ФИНАНСОВЫЕ ИНСТРУМЕНТЫ ГОСУДАРСТВЕННОЙ ПОЛИТИКИ ПРЕДУПРЕЖДЕНИЯ ТЕРРОРИСТИЧЕСКИХ АКТОВ В УКРАИНЕ}

Аннотация. Цель статьи заключается в определении финансовых инструментов механизма реализации государственной политики противодействия террористическим проявлениям на неподконтрольных со стороны Украины теріторіях Донецкой и Луганской областей. Методика. В рамках научного поиска наиболее действенных подходов национального уровня по предупреждению угрозы международного терроризма в условиях глубокого внутриполитического кризиса и чрезвычайно сложного экономического положения, с целью повышения эффективности деятельности органов государственного управления при формировании и реализации государственной политики противодействия терроризму в Украине, в работе проанализированы международные и отечественные нормативно-правовые акты относительно предотвращения финансирования терроризма, рассмотрены факторы, которые влияют на ухудшение социально-экономического состояния временно оккупированной части Донбасса. $B$ результате сформулировано определение финансовых инструментов антитеррористической политики, разработано и предложено проведение ряда организационных мероприятий в целях предотвращения финансирования терроризма. Практическое значение. Разработан вариант классификации основных противоправных механизмов, которые могут быть использованы для финансирования террористической деятельности на неподконтрольной Украинской власти части Донецкой и Луганской областей, разделив их на внутренние и внешние. Учитывая исследованные факторы и классификации процессов финансирования террористических проявлений на востоке Украины, в работе раскрыты пути поставки товарно-материальных ценностей на неподконтрольные районы Донецкого региона, что в дальнейшем поступают до незаконных вооруженных формирований, с целью отклонения от уплаты пошлины соответствующим государственным органам Украины. Значение/оригинальность. Внедрение разработанных финансовых инструментов государственной политики противодействия терроризму позволит получить такие позитивные результаты:

- обеспечит системную реализацию государственной политики в сфере предотвращения и противодействия легализации (отмыванию) доходов, полученных преступным путем, или финансированию терроризма;

- повысит соответствие национальной системы предотвращения и противодействия легализации (отмыванию) доходов, полученных преступным путем, или финансированию терроризма с международными правовыми стандартами;

- улучшит стимулирование притока иностранных инвестиций в национальную экономику.

Однако, определение эффективности вышеизложенных мероприятий должно происходить согласно принципов методологии экономического анализа государственной политики. 